\title{
Obituaries
}

\section{DONALD SHAW}

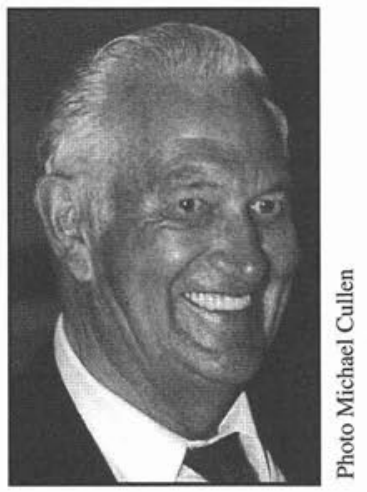

The Ottawa Valley lost a giant of a man with the passing of Donald Shaw, the semi-retired vice-president of Herb Shaw and Sons Limited.

Mr. Shaw will be remembered in many different ways by many different people - people from all walks of life. He will be remembered for his generosity - helping young people pursue higher levels of education, helping victims of fires and floods, helping employees who needed assistance because they had experienced personal difficulties, helping communities to make their communities better. He'll be remembered by his close friends as a loyal and true friend. And he will be fondly remembered by his family whom he adored.

No one will ever know all of this man's good deeds in life. We'll just keep hearing about them as time passes.

And what is really remarkable about Donald Shaw is that he did not share his financial and other resources to be put on a pedestal, to seek the kind of publicity that so many others look for by performing acts of kindness. Rather, in his quiet and unassuming way, he assisted people because he was a true humanitarian. That was his nature and that is what he will be remembered for the most.

But he'll also be remembered in his own industry as a respected lumberman, a good employer, a man with vision, a clever businessman and a friend of the forests.

Donald Shaw had many reasons to be proud, but he was not one to boast. Among the things he was proud of were the family's 150-year-old lumber and pole business, the oldest family-owned business in the country; his family, and Shaw's Highland Ranch in Wilberforce Township where the Shaw family got their start in Canada. The ranch was his retreat, a place where he loved to be.

He never forgot his roots, never forgot where he came from.

Donald Shaw got a lot of joy and pleasure out of life but he gave it all, if not more, back.

His family can be very proud of the legacy he left behind.

\section{SHELDON WILLIGAR}

On Tuesday, June 23 we lost a well known and respected forester colleague. Sheldon Willigar, 53, of Masstown, Colchester County, died suddenly in Parrsboro. His untimely death leaves behind his wife Carole, mother Rachel and sisters Ruth and Minnie. He will also be missed by his former fellow workers in the forestry industry, especially those of the Department of Natural Resources for which he worked 20 years, mostly in the Bible Hill Office.

The honest, practical and professional manner in which Sheldon conducted himself over the years was admired and valued by all who knew him. His major responsibilities over the years composed a workload capable of keeping two or three average workers busy and challenged. In recent years he capably oversaw the regional Crown land programs for Colchester, Cumberland, Pictou, Hants and Halifax Counties which includes over 15 different large Crown land license agreements and long term leases. As well, Sheldon played a key role in the relatively new DNR integrated resource management planning process for Crown lands which we are presently well into. He was a member of many committees over the years, including the RPF Committee for the Canadian Institute of Forestry (Nova Scotia Section). He and several others have been working for several years to develop a Registered Professional Foresters Act that would be legislated to provide a formal process which would ensure accountability of professional foresters who work in the forestry sector of Nova Scotia.

Although Sheldon Willigar has left us, he is not forgotten.

\section{G.H.U. "TERK" BAYLY}

Mr. Bayly, born in Toronto, graduated with the degree of B.Sc.F. from the

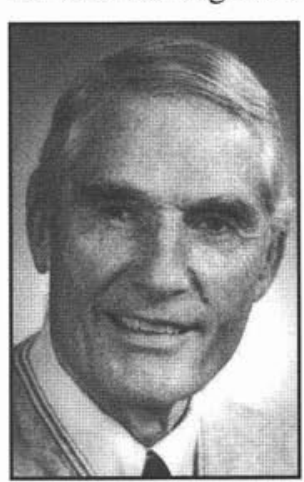

University of Toronto in 1939 and M.Sc.F. from the same University in 1952. His father, George, had graduated from the Faculty of Forestry at Toronto in 1927. Terk served as a pilot with the RCAF from 1940 to 1945 and was awarded the Distinguished Flying Cross.

He joined the Ontario Department of Lands and Forests in 1945 in the Reforestation Branch. He was promoted to Chief of the Branch in the early 1950 s and soon initiated a program to extend the Branch's operations from Southern Ontario to the north. Until that time the Branch had focussed its efforts on reforestation of waste lands and abandoned farm land in the south. The new program extended regeneration to forest industry cutovers in Northern Ontario.

Terk was appointed assistant deputy minister of Lands and Forests in 1957 and deputy minister in 1966. During his fiveyear term as deputy minister he served on the Coordinating Committee of the Canadian Council of Resource Ministers, the Advisory Committee on Regional Development, the Computer Services Board, the Civil Service Commission and the Committee on Government Productivity, (COGP). The responsibilities at the provincial level were all key roles in sweeping changes taking place in Ontario at a time of significant growth and redirection. Terk Bayly's role on the COGP was particularly key. He was the principal line deputy minister on a committee that influenced the structure and operations of the Ontario Public Service for the next quarter century.

Terk was appointed Secretary of the Management Board of Cabinet in 1971. This Board, formerly Treasury Board, was the key facilitator in changing the way the ministries operated in delivering services to the public. Terk supported the change from a sole focus on input con- 


\section{Section News / Nouvelles des Sections}

\section{SOUTHERN ONTARIO}

The Southern Ontario section held its Annual General Meeting on June 20 at the Mansfield Outdoor Centre and the Dufferin County Forest.

Outgoing Chair Ken Elliott reviewed the year in the Section and in the CIF. The ed, the new Council for the Southern Ontario section is as follows:

Chair/Director

Mike Clarke

Past Chair

Vice-Chair

Ken Elliott

Secretary

Treasurer

Communications

Newsletter Editor

Jim Coles

Caroline Mach

TBA

Arne Aiking

Promotion \& Issues Doug Wells

Public Eduation Kirk Biggar

Working Groups \&

Continuing Education John Nolan

Student

TBA

The remainder of the business meeting was conducted by incoming Chair Mike Clarke. The Treasurer's report shows that financially we're not in too bad Nominating Committee report was adopt-

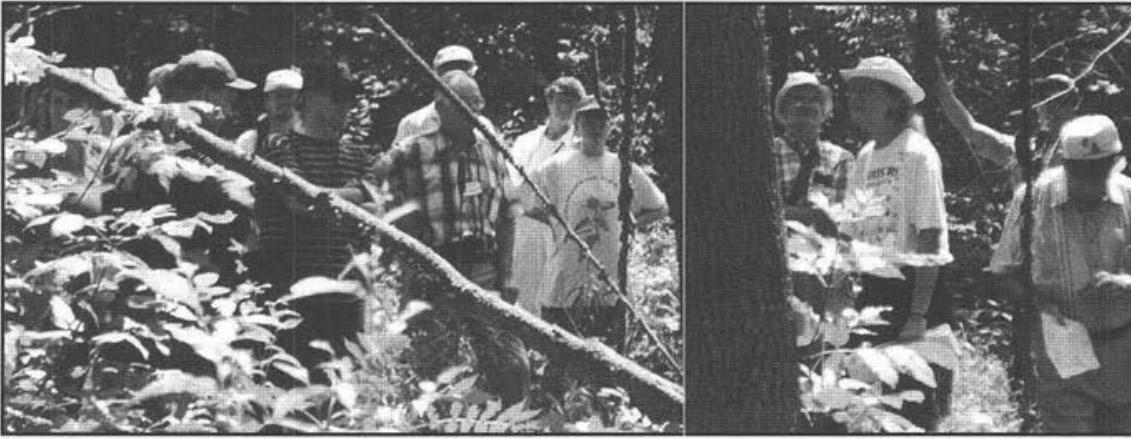

CIF-SOS members learn about the research into red oak regeneration ongoing in the Dufferin County Forest from Caroline Mach, County Forest Manager and SOS Secretary. shape, if our membership does not decline further. Four newsletters were produced during the past year.

Outgoing Communications Councillor Caroline Mach reported that she had made several contributions to The Forestry Chronicle on behalf of the Section and put together a fact sheet describing the Southern Ontario Section that now accompanies all membership application forms from

\section{Obituaries}

trol to a dual focus on outcomes achieved for resources expended. He also served on a number of key boards and advisory committees to government and was a member of the Ontario Joint Committee on Physicians Compensation. He was transferred to Deputy Provincial Secretary for resource development and retired from the Ontario Government and that position in 1975.

Terk was appointed in 1976 by Premier William Davis as a member of the Commission on Freedom of Information and Individual Privacy.

In 1981, Terk was appointed to the Ontario Heritage Foundation (OHF) and was Chairman of its Heritage Trust Committee. He devoted considerable time and energy to developing "built" and natural heritage programs within the $\mathrm{OHF}$ and was the inaugural Chairman of its Niagara Escarpment Committee in 1985. In March 1986, he was appointed Chairman and CEO of the OHF, and served in that capacity until Premier David Peterson asked him to assume the position of Chairman of the Niagara Escarpment Commission in March 1987.
He served as Chairman until August 1993.

Terk was involved in the establishment of Ontario's Natural Heritage League and served as its first Coordinating Committee chairman from 1983 to 1986 , and overall chairman in 1986-87. Under his leadership, the League - a network of 28 private and public organizations and agencies - became a significant force in the identification, protection and management of Ontario's natural heritage. Terk is remembered for his development of conservation trusts because enormous perseverance was required to overcome legal impediments to this concept.

Terk's hobbies included flying and racing of gliders, white water canoeing and voyageur trips in Arctic Canada. $\mathrm{He}$ was an instructor for the Beaver Valley Soaring Club.

Mr. Bayly is survived by his wife Fay, a daughter Ann, sons John and Richard, six grandchildren and one great grandchild.

Bob Carmen Toronto, Ontario head office. (Also, in her role on the local stewardship council, she did us a big service by including us in the land stewardship tent at the 1997 International Plowing Match.)

Public Education Councillor Kirk Biggar reviewed a year of major Southern Ontario section input to the Kortright Centre's education program.

John Nolan reported on the successful symposium co-hosted by our Section at the University of Guelph on March 4.

Future events were also explored. Andy Kenney proposed a fall meeting with urban forestry people at the University of Toronto to meet with students there and explore linkages between ourselves and them. Earl Dertinger, Stewardship Co-ordinator for North Simcoe has offered to host an event late next winter to examine stewardship, county tree cutting by-laws, and county forests.

A brief, informal members' forum got into such things as reversing membership decreases, the forestry situation in southern Ontario, a statement of purpose for the Section, and the development of the section website by Ed Bevilacqua (For those with Internet access, the site is located at www.forestry.utoronto.ca/cifsos.)

Terk Bayly's death on June 9 at age 80, at his home near Meaford, was noted. Terk was a pioneer of the southern Ontario reforestation movement, after a distinguished wartime flying career; he later became Deputy Minister of the Department of Lands \& Forests; after retirement he chaired the Ontario Heritage Foundation and the Niagara Escarpment Commission. 